\title{
TOPICALITY OF COMMUNICATION TECHNOLOGIES AND INFORMATION (ICT) IN TEACHERS LIFELONG LEARNING AND TEACHING
}

\author{
Juan Campechano Covarrubias \\ National Union of Education Workers (SNTE) - Unit 141 of the National Pedagogic \\ University (UPN)
}

\begin{abstract}
This work is an advance of research in process about how is the incorporation for the use of Information Technologies and Communication (ICTs) by teachers of basic education in Jalisco State in their educational practice. The problematical is delimited, by two factors: the level of infrastructure and equipment of schools and on the other hand, the attitudes of teachers towards ICTs.

It seek investigate as the main purpose, how the teachers appropriated technologies from different programs for the use of ICTs that has implemented by the Secretary of Public Education in their teaching. It is assumed that the reforms are not hegemonic mechanisms that permeate the educational practices but are contexts, attitudes that enable to teachers of basic education the differentiated appropriation of ICT.
\end{abstract}

Keywords: Information Technology and Communication, Teachers lifelong learning, Teaching Practice, Basic Education.

\section{Introduction}

In recent years, we had witnessed about profound changes in everyday life that are being introduced by the Information and Communications Technology (ICTs); the ability to communicate in real time with audio and video to various locations anywhere on the planet, in search of information on almost all the known, sales and purchases online, to conduct financial transactions, perform searches and establish personal relationships through the network, among others.

Education is also influenced by advances in ICTs. To point out some background, correspondence education, which employed the postal sector and mailed the study materials (Federal Institute for Teacher Training 1945-1971). The various courses offered by radio and television, such as English, math, Channel 11, National Polytechnic Institute and channel 22 of the National Council for Culture and Arts. In the late 1970s, teaching machines were introduced, based on the theory of operant conditioning by the American psychologist BF Skinner, which passed almost unnoticed for the teachers.

Later work is the open and distance learning (ODL) start by various universities and institutions of higher education as the National Autonomous University of Mexico (1972) and the Instituto Tecnológico de Estudios Superiores of Monterrey (1997). Although the incorporation of ICTs into education has been consolidated in higher education, not so with other levels. Cesar Coll and Carles Monereo say: 
„ICTs in general and the Internet in particular, provide an excellent opportunity to leap towards higher quality education based on principles of solidarity and equality. However if not graduated while the jump, if we do not start from different social and educational realities, with their successes and shortcomings, we can end up taking a leap into the void and expected educational advancement can remain an economic and commercial plus operation." (Coll and Monereo, 2011; 49)

In reviewing what happens ICTs in basic education, it seems that by simply entering technological devices and refer to government plans, the desired effects is obtained. But so far, notably absent from the concerns to introduce ICTs in education are the elementary school teachers. With their attitudes and fears towards ICTs, knowledge, jobs that make them who have one or several pc, or tablets, in their classroom, whether they have or have not internet connection, etc. This research is part of the activities of the Research Unit of Collegiate Education, Cultural Development and Professional Advancement of the National Executive Committee of the SNTE. With this, will seek to provide elements to understand how teachers are incorporating ICTs into their daily practices, especially using them to get results in student learning.

\section{Elements to think the differences in access to ICTs.}

We can start problematize the issue of ICTs and their incorporation into educational practice by teachers in basic education, from the characterization of what some authors call the network society (Castells, Tubella, Sanchez and Roca: 2007). Other authors call knowledge society or information society (Sakaiya: 1995), which consists of:

„On four main elements: the revolution in information and communication technologies, also related to the revolution in genetic engineering; the model of network organization as the predominant form of human activity in all areas; the crucial role of knowledge generation and information processing as sources of power, wealth and cultural significance; and global interdependence of societies, including through integration into global communication networks strategically dominant activities in each society. Thus, the net society is a global social network, but with specific manifestations in each of the societies in which people from different cultures stories and lives". (Mominó, Sigalés and Meneses: 2008: 21)

Currently one of the economic indicators of economic competitiveness of countries is related to the use and impact of ICTs, the Networked Readiness Index (NRI) of the World Economic Forum which is published annually since 2002. It measures both the regulatory environment and competition as the penetration and use of online services and hence it is said that:

„In 2010, Mexico ranked 75 globally and 12 of 25 for the Americas, below Argentina, Uruguay, Chile, Brazil, Venezuela, and Peru, and above Colombia, 
Ecuador and Paraguay. The relative position of Mexico has not changed in recent years occupied places 77 and 74 in 2007 and 2008 respectively „(Palacios, Flores-Roux and Garcia Zaballos, 2013; 17).

One of the main points so that they can incorporate ICTs in schools is the existence of computers and internet in schools, on this point in the study "Assessment of the ICTs sector in Mexico" a series of graphs are presented what show Mexico's comparative position relative to other countries, in relation to public access to computers, say:

,$\ldots$ In Mexico also remains a gap in access to computers. To give an idea of the country's position in this area, a basic comparison is the current penetration of computers per household, which in Mexico is equivalent to the European level that had 16 years ago (ITU, 2009), and it does not compare favorably with other countries in Latin America" (Palacios, Flores-Roux and Garcia Zaballos, 2013; 23).

So, that despite the size of the country and the economy of Mexico, there is a gap with respect to the countries of the Organization for Economic Cooperation and Development (OECD) of that we are part. Although some Latin American countries, for example Chile and Brazil. This difference is known as the digital gap, which can be referred to countries, regions and individuals.

„The OECD defines” digital gap ,as the difference between individuals, households, businesses and geographic areas at different socioeconomic levels regarding opportunities to access ICTs and Internet use." (Palacios, Flores-Roux and Garcia Zaballos, 2013; 57-58)

Then, first there is a digital gap between Mexico and the countries with they is a partner, mainly OECD, but that study also shows the gaps between different regions, groups and individuals for their income level. It is also important to note that the use of smart phones and computers is related to income levels and social position of individuals. The same report notes the high cost of telephony and Internet services, lack of competition in services as a company accounts for most of the market, and poor services in rural areas. In the case of the country in regard to having and using computers in education, include the statement by the INEE say that:

„There is a significant gap in the provision of computers to elementary schools: in the 2010/2011 school year, less than half of primary schools $(49.1$ percent) had available one computer for educational use ... In other words, it did not have computers for educational use little more than half of primary schools ... Neither the universality of this minimum access other service types is achieved" (INEE cited by Mendoza Sanchez, 2013; 35).

In the case of our state, in the report 2013 prepared by the Ministry of Education Jalisco (SEJ) based on data of the Certificate of Factors Associated with Learning (CEFAA in Spanish) it can be seen that there are differences if having a computer in home and Internet access, both teachers and directors of 
basic education on middle and higher education, among Rural, Urban and private schools, where the lowest percentages are teachers of the rural areas, as shown in the following graph:

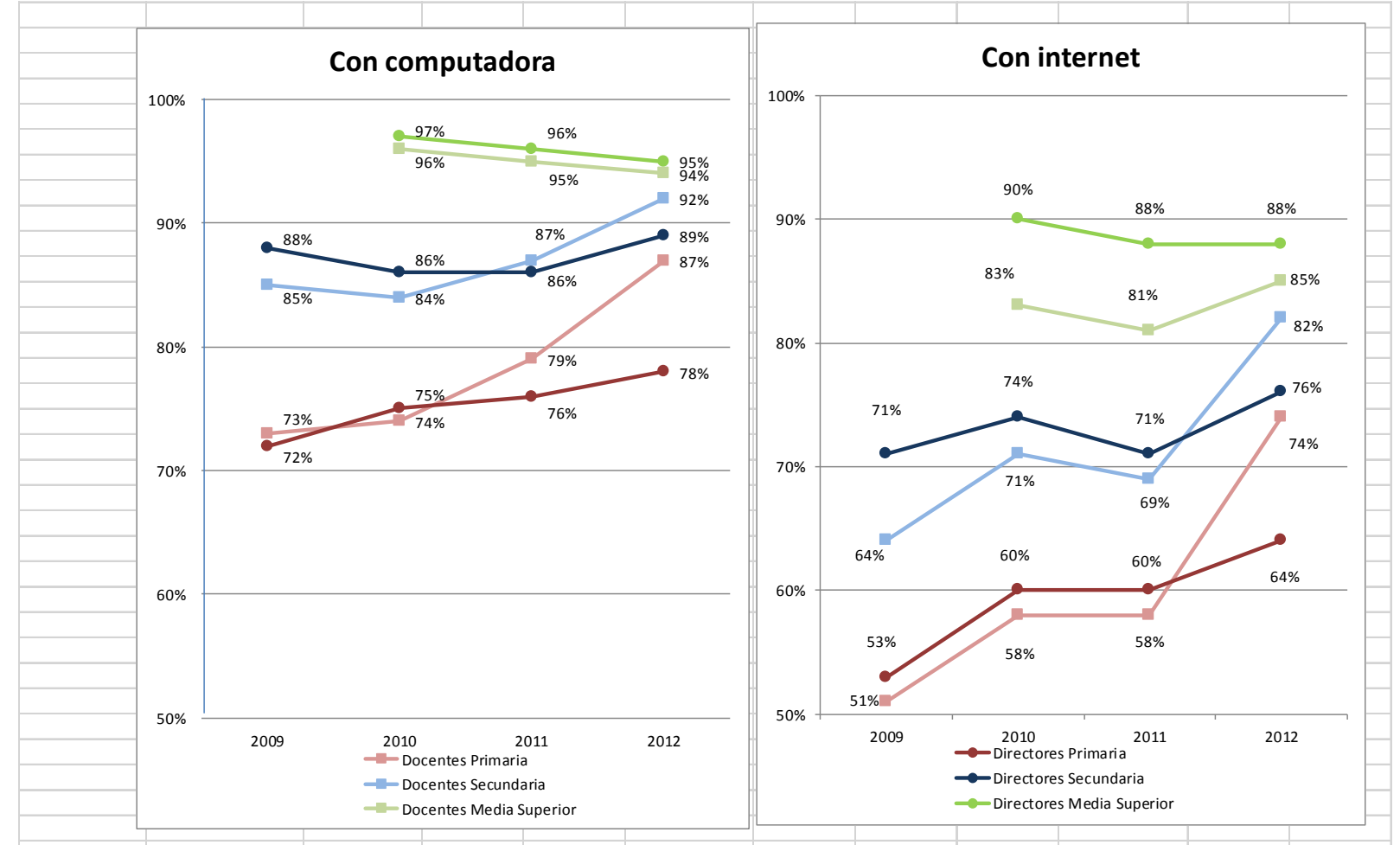

Figure 1. History headmasters and teachers with computer and Internet at home

Certificate of Factors Associated with Learning (CEFAA) $(2013,2)$ SEJ

In this contextual framework, concern for the subject field of ICTs that therefore the possibility of having a computer and the internet, there is not equality conditions and there is an unfavorable condition of basic education teachers, mainly in rural areas. Then it is necessary to take in account the characteristics of our country in terms of social inequality, inequity, cultural diversity and other elements that enable the use of computer equipment and their conditions to have, their ability to use and the little accessing internet.

\section{Plans and Projects SEP referring to ICTs in Basic Education}

Another key element is the set of policies and programs or projects for the incorporation of ICTs in public education by the government in turn. In this regard Tapia (2013) which presents the projects to introduce ICTs and digital technologies to public education and specifically in the Federal District, the author recounts, seen in the following table, which in part Final incorporate Digital Skills Program for All, proposed by the government of the Lic. Felipe Calderon Hinojosa and Mi compumx government program of Lic. Enrique Peña Nieto. 
SOCIETY. INTEGRATION. EDUCATION. Volume IV

Table 1. Programs and projects implemented by the Ministry of Education

\begin{tabular}{lll}
\hline Year & Federal Program & Local Program \\
\hline $\mathbf{1 9 8 3 - 1 9 8 5}$ & Galileo & \\
$\mathbf{1 9 9 0 - 1 9 9 4}$ & Coeeba & $\begin{array}{l}\text { Computer Laboratory of } \\
\text { Education (LIE) (SSEDF) }\end{array}$ \\
$\mathbf{1 9 9 5 - 1 9 9 6}$ & & $\begin{array}{l}\text { Media Classrooms } \\
\mathbf{1 9 9 7}\end{array}$ \\
$\mathbf{2 0 0 0}$ & School Net & \\
$\mathbf{2 0 0 4}$ & Iztapalapa)
\end{tabular}

The SEP Curriculum 2011 contains significant differences compared to previous plans, just to point out four aspects; seeks to articulate the pre-school, primary and secondary, a second aspect is the competence-based approach, the introduction of curriculum standards and learning outcomes, academic foundations for the development of digital skills as a transversal axis in the curriculum.

An innovative aspect compared to previous plans and programs of study is the inclusion of a section on MANAGEMENT FOR DEVELOPMENT OF DIGITAL SKILLS, in which considerations about the importance of Information Technology and Communication point (TICs), which are based on the consideration that „The absence of an information and communication technology policy in public school increases inequality among countries and people" (SEP, 2011; 53)

In the same document cited the potential of ICTs in informal settings states:

"Also, as UNESCO says..." one of the most notable phenomenon of the new education paradigm is the multiplication of the potential learning centers. If education becomes a continuous process, that is not limited to a determined space and time, it is important to value informal learning, whose potential is now reinforced by the possibility of access, offered by new technologies.

The context is clear, no educational reform can avoid the Standards of Digital Skills, they describe student knowledge and know how when using ICTs. They are fundamental to developing competencies throughout life and favor the insertion in the base information society.

The profiles of students competent in the use of ICTs must be related to the Basic Education school periods and to the equipment model"(SEP, 2011; 54).

To meet the standards of Digital Skills have been considered in the Plan 2011, two strategies: Media Classrooms and telematics Classrooms. 
Table 2. Models of equipment implemented by the SEP (2011)

\begin{tabular}{|l|l|}
\hline SCHOLL PERIOD & $\begin{array}{l}\text { EQUIPMENT MODELS FOR THE } \\
\text { ACHIEVEMENT OF THE STANDARDS FOR } \\
\text { DIGITAL SKILLS }\end{array}$ \\
\hline $\begin{array}{l}\text { Second school period, at the end of } \\
\text { the third year of primary. }\end{array}$ & $\begin{array}{l}\text { Media room and computer laboratorios, where } \\
\text { students interact with ICTs }\end{array}$ \\
\hline $\begin{array}{l}\text { Third scool period, at the end of the } \\
\text { sixth year of secondary. }\end{array}$ & $\begin{array}{l}\text { Digital classroom 1 to } 30 \text { model, where students can } \\
\text { interact with the ICTs. } \\
\text { The state education authorities will add three devices } \\
\text { pre classroom. }\end{array}$ \\
\hline $\begin{array}{l}\text { Forth school period, at the end of } \\
\text { the third year of secondary. }\end{array}$ & $\begin{array}{l}\text { Digital classrooms 1 to 1 model, where students } \\
\text { interact with the ICTs }\end{array}$ \\
\hline
\end{tabular}

Source: SEP, 2011, Agreement 592, Pags. 54

Because of its importance to the issue, I will reproduce an extensive quote of reference document:

„The Standards of Digital Skills are aligned to the Unesco International Society for Technology in Education, and are related to the teachers competency standard „Learning projects integrated to the use of information technologies and communication ,(2008), designed by the Committee for the Management of Competencies in Digital Skills in the Learning Process with the corresponding performance indicators.

The performance indicators for the use of ICT for teachers are:

- Use digital tools and resources to support the comprehension of knowledge and concepts.

- Apply acquired concepts to generate new ideas, products and processes, using ICTs.

- Explore questions and topics of interest, plan and manage investigations, using ICTs.

- Use communication and collaboration tools such as e-mail, blogs, forums and instant messages, to work in a collaborative way, exchange opinions, experiences and results with other students, as well as plan and use creative thinking.

- Use models and simulations to explore some topics.

- Generate original products with the use of ICTs, which use critical thinking, creativity and problem solving is used.

- Develop investigations or projects to solve authentic problems and/or meaningful questions.

- Use productivity tools, such as word processors to create documents or research; a software to present research activities and software for process data, communicate results and identify trends. 
- Use social networks and participate in learning networks using the rules of digital etiquette.

- Use software and hardware in a responsible manner, working individually, in pairs or in teams.

- Use Internet and digital tools in an ethical, safe and responsible manner.

To integrate the actions for the use of ICTs, the strategy Digital Skills for All (HDT for its initials in Spanish), was created, whose origin can be found in the 2006-2012 National Education Plan (Prosedu for its initials in Spanish), that establishes as one of its strategic objectives ,drive development and the use of information and communication technologies in the education system to support student learning, broaden their competencies for life, and enable their insertion in the society of knowledge." (SEP, 2011; 54-55).

Some elements of the agreement are that an essential module in the use of technology in school is the connectivity of schools to high performance links.

In Mexico it was decided, as referenced in this document for more equipment and connectivity of schools, while developing a pedagogical model for the training and certification teacher (accompaniment) and promote the Instructional design from curricula and school management modules online.

„The Digital Skills Strategy considers the following components:

- Pedagogical. It includes the development of educational material: learning objects, suggested class plans and items that facilitate the management of standards stated in the Programs of Study.

- Operation. Its purpose is to organize, systematize and share information in the Digital Skills Program (classroom, school, state and country).

- Accompanying. Its objective is to support teachers, solve doubts and guide them to better take advantage of technology in education. It includes the use of technology in education and certification.

- Connectivity and infrastructure. It comprises all the equipment, connectivity and the necessary services for the classrooms to operate correctly, and enables a greater level of interaction between children and computers in order to decrease the gap in access to information." (SEP, 2011; 57).

Through each of the periods indicated in the table mentioned above, are set out in detail, actions to achieve the performance indicators.

Thus, it is intended to seek to understand the articulation of a compromise between the subjective structures of the subject and the structural determinants of the social, cultural and educational system, at what they do together teachers and students. I believe that this point are the practices, which somehow structures express thoughts, ideas, attitudes, among others. 


\section{The Practices Teachers and their Conceptions about ICTs}

Assuming as provisional definition that education is a set of actions and meaning by looking operate changes in others, in order to their transformations in their know, that they do or that they want. I will seek structures that enable educational practices and how they are articulated with the use of ICTs.

Mariano Palamidessi $(2006 ; 10)$ says „ICTs are not neutral devices. They are frames of artifacts, techniques, skills and knowledge that are linked to social practices, knowledge and guidance systems and interpretation of the individuals and groups that use them. To a large extent, how the technologies overlap in the production of social practices depends on the ability of individuals, institutions and societies have to build and recreate knowledge and meanings around their potentialities and their uses."

It is generally considered that there are two types of structures that has influence in the types of behavior of individuals, on the one hand, social structures and cultural order. This type of structures we mean when we think about how they are organized and regulated institutional practices, in this case, schools. These structures are mediated by frames or networks senses or meanings. The set of social actions at school are imbued with meanings and representations.

Diego Lizarazo Arias says:

„This is a density of meanings and representations that anticipate the use and define the kind of links and actions developed by the actors. The use of resources is steeped in stories, fears, expectations or opinions about technology that are circulate and exchange in the social space. All technology is a field of cultural representations; there are not in society with computers or electronic boards per se, technologically pure, because they only have status in human dynamics that incorporate them, reject or reused. Technology is always techculture and cultural representation is precisely that which is sought in this book." (Lizarazo Arias and Andión Gamboa, 2013, 18)

As the authors point out, fear of teachers to be exhibited by their limitations to use ICTs, to decompose it and they have a liability for them or ask them for repaired, or they think that are very complicated and difficult to use artifacts, etc. They are some of the elements that come into play when wanting to use ICTs in school contexts.

Some politics think that the presence in classrooms of ICTs, will be sufficient to transform the pedagogical practices of teachers but is a misconception, in a study by the Center for Educational Studies, James B., Knight Á., And M. Gómez Dominguez C, (2013) say

... the relevance of ICT in education is result of the teaching methods and learning activities, as these motivate one kind of learning or another learning; for example, with expository teaching, ICTs promote reception learning; oriented with active and participatory construction of knowledge by the students 
education, ICT facilitate discovery learning. In this sense, teachers use technology to substantially the same thing that they were doing, but faster attractive and dynamic. (Santiago Caballero Á, Gomez M and Dominguez C, 2013; 101-102)

The possibility of joint educational practices and relevant elements to educational purposes that are sought, result from the interaction of both the cultural elements in social order as the elements of thought, intelligence, perception, interpretation, decision making structure the teaching. Some of them settled based in schemes of practice that has built through his personal history as a teacher.

The purpose of the search, will find regularities in thought-representationsstructures of meaning that are causing and promoting certain types of practices. In a genetic process those who have less educative results, and educational implications, whit the other that have best implications and educational outcomes process.

\section{Elements for Problem Background}

In the case of my research project assumption that there are different ways and reasons through which and by which, teachers approach, to know and use information communication and technologies in education. For teachers, it is likely that age, knowledge, attitudes, familiarity and usability of ICTs for their work, are factors that influence their incorporation in teaching, so that for a digital immigrant does not It is easy, nor is done automatically, while young teachers may be are more familiar, but not necessarily know and use technological devices for the purpose of educating. He said about Prenski

What should we call these "new" students of today? Some refer to them as the N-[for Net]-gen or D-[for digital]-gen. But the most useful designation I have found for them is Digital Natives. Our students today are all "native speakers" of the digital language of computers, video games and the Internet. So what does that make the rest of us? Those of us who were not born into the digital world but have, at some later point in our lives, become fascinated by an adopted many or most aspects of the new technology are, and always will be compared to them, Digital Immigrants. The importance of the distinction is this: As Digital Immigrants learn - like all immigrants, some better than others - to adapt to their environment, they always retain, to some degree, their ,accent," that is, their foot in the past." (Prenski, 2001, 1-2).

However, despite the use of ICTs just joined in the plans and programs of study in our teacher training institutions, the fact is they have been various proposals for several years to incorporate ICTs into the educational process.

The Information and Communications Technology (ICT) are elements that permeate increasingly in everyday life of people. We can no longer ignore, or pretend to ignore its impact. The school, educational communities and 
educational processes must take them as an opportunity and not with indifference or as a threat.

In the future, the teacher must develop skills to exploit them in their educational task. However, the complexity of features that teachers have the fully incorporate ICTs into teaching practice, it will not be an easy or short-term task. It will require a knowledge and appropriate to gradually introduce teachers in the knowledge and use of ICTs in their practice and professional development strategies.

At the present time is presented as necessary to know how teachers are appropriating ICTs and uses for them in their teaching.

\section{The Problem}

The reality of the educational process is complex, it's just looks like easy and simple the people say about it from outside. There are an assumptions that me as an educator and trainer of teachers have developed when seeking to explain, understand and comprehend educational phenomena and the role of ICTs in them.

- There is a fundamental difference between what say the official documents (laws, regulations, plans, programs and projects of governments) and how the content or was said in these documents is implemented in classrooms, in the practical, in the everyday actions of teachers, directors and students in classrooms and schools.

- We can think the elements that are introduce rapidly, the changes, innovated or new technological devices or processes for communication and information. But these are incorporated unevenly, by income, by cultural references, training or learning processes by aspects of the personality of the teacher who assumed. The diversity of how teachers are incorporating ICTs is as elements of context and personal environment who want to incorporate into the analysis.

- Is not an association of the educational process from technology, from hardware or software, from platforms and social networks, from the processor type or speed internet, I see from the practices and thoughts of teachers from characteristics of schools, classrooms, students. From the diversity of learning that students seek to achieve. Within the educational processes, technological devices are just a small part of what can be taken in count.

- Speaking this about the students in $5^{\text {th }}$ and $6^{\text {th }}$ grade in basic education, $1^{\text {st }}, 2^{\text {nd }}$ and $3^{\text {rd }}$ secondary (basic education) we are thinking of children aged 10-11 years to 15-16 years. With features of the transition from childhood to adolescence. With the experience of change a teacher each hour during the school day, because in elementary school each 
teacher for several subjects. With different times, with different modalities.

- Teachers from schools with different characteristics; educational background (normal school, university, technological), years of experience, to the attention of various subjects in primary, attention to one subject in secondary school education. Involved in different experiences with technology or devices (Red Escolar, Enciclomedia, Digital Skills for All, My compumx). Years of experience in teaching work, availability and infrastructure of computers and internet, etc.

- The main assumption is that I consider to educational practice as a series of deliberate and systematic actions through which someone searches transforms for another or others in their state or condition of what they know, can do or want to do, around some contents for learning. ICT will be used as an element that can articulate the practices to create, generate, enabling experiences and processes through which students learn.

In order to propose alternatives to improve training and professional development of teachers through ICTs, should be based on knowledge and use made of them, for which arise the following questions.

\section{Guiding questions:}

- What educational use give teachers to ICTs in Jalisco, mainly related to the development of learning experiences for students, identified in the plans and curricula of basic education?

- Is it possible to set different evolutionary stages, or levels that define the process of knowledge and incorporation of ICTs by teachers of basic education Jalisco in their teaching practice?

\section{Questions arising:}

- What is the knowledge and mastery which have teachers of elementary schools about ICTs in the Jalisco State?

- What are the attitudes of teachers regarding ICT and use by teachers and students in basic education schools in the State of Jalisco?

- What conceptions have Jalisco teachers in primary and secondary education about the impact and potential uses of ICTs in basic education?

- What knowledge have Jalisco teachers on skills and cognitive processes that occur in basic education students that using ICTs?

- What use the teachers of primary and secondary schools in Jalisco do of ICTs and how much students use them as a learning and finding information?

- What elements must contain an educational proposal for teacher training for the use and incorporation of ICTs in teaching, and for the new teachers to take a work place in basic education? 
These questions need to be answered prior to the generation of proposals for development of ICTs in education by teachers. Several authors have pointed out the various myths about virtual education and the use of ICT in education. (Villegas and Restrepo, 2012)

\section{Purposes Research}

Main Purpose

- Search whether there is an evolutionary process, stages or levels through which teachers of basic education in Jalisco are incorporated ICTs in their daily practice, meaningful and educational purposes.

Secondary Purposes

To know the level of knowledge and use which teachers of primary and secondary schools in Jalisco on communication and information technologies.

Define the use forms of ICTs by teachers in primary schools of Jalisco.

To know if teachers use ICT in everyday practice performing in elementary schools in Jalisco.

Establish links that teachers in basic education established between ICTs and their teaching in basic education in the State of Jalisco.

Generate a pedagogic proposal for the use of ICT by teachers in primary and secondary education.

\section{Methodology.}

Develop a study by a representative sample of teachers in primary schools of the State of Jalisco. There will be select by their experience with their participation in some government programs (Enciclomedia, HDT).

Propose six variables and indicators for the study;

- $\quad$ Age of teachers;

- Time in teaching.

- Courses or knowledge among teachers of ICTs.

- The use that teachers make of ICTs in the classroom.

Teachers-conceptions of their income to the educational process with TICs.

- Use of ICTs by teachers according to (primary and secondary) education.

Context elements to take in account;

- Terms of school around the number of computers that have per pupil, if the teacher has a computer, internet connectivity and airtime for students.

The sample will be random and proportional to the population of teachers for 50 and 60 in elementary and 1o, 2o y 3er grades, according to primary and secondary schools in basic education of Jalisco. They are segmented according to primary and secondary levels. And their participation in programs with TICs.

Is established differences in the type of training in Normal schools at every educative level; source administrative control type (state or federal). According to the embodiment at; for example primary, telesecundaria, secondary general. 


\section{SOCIETY. INTEGRATION. EDUCATION. Volume IV}

A questionnaire, or if necessary, it will be as a basis for an interview will be used. This for make a teacher's selection for the field work. There will be selected for; the participation in SEP programs with ICT (Enciclomedia, Digitals Skills for All, etc.), they knowledge and skills about ICTs, and the use in the teaching with their students.

This questionnaire after the selection for use the observation of teacher's practice in classrooms. For to observe the differences that they have in their think, their ICT skills and their use the teaching practice

The development of the research process will be adjusted if necessary.

So far I don't had found studies addressing the relationship of ICTs, knowledge, use in teacher training and competency development for educational use in everyday practice of teachers in elementary schools.

\section{References}

Aguerrondo, I. y Braslavsky, B. (2003) Escuelas del Futuro En Sistemas Educativos del Futuro. ¿Qué formación docente se requiere? Papers Editores. Buenos Aires Aguerrondo, I. y Pogré, P. (2001), Las instituciones de formación docente como centros de formación pedagógica. Buenos Aires, Troquel.

Ardoino, J. (2001), La trayectoria de desarrollo profesional docente. Algunos conceptos para su abordaje. Seminario de doctorado, Universidad de París VII.

Bernard, Miche (2006) Formación, distancias y tecnología. Ediciones Pomares, México.

Castells, M. Tubella, Imma. Sancho, Teresa, Roca, Mrixtell (2007) La Transición a la Sociedad Red. Editorial UOC-ARIEL, Barcelona

Castells, M. (2001), The internet galaxy, Oxford, Oxford University Press, p. 278.

Secretaría de Educación Jalisco (2013) Cédula de Factores Asociados al Aprendizaje (CEFAA)

Centro de Estudios Educativos (2011) De Enciclomedia a Habilidades Digitales para Todos: Recomendaciones para la incorporación de tecnologías de la información y la comunicación a los procesos de enseñanza-aprendizaje en las aulas del nivel primaria en México. Revista Latinoamericana de Estudios Educativos.Volumen XLI, $3^{\circ}$ y $4^{\circ}$ trimestres 2011, Números 3 y 4, pags. 5-14

Coll, César y Monereo, Carles (Eds.) (2011) Psicología de la educación virtual. Ediciones Morata, Segunda Edición, Madrid.

Crook, Ch. (1998) Ordenadores y aprendizaje colaborativo. Ediciones Morata, Madrid.

De Moura Castro, Claudio. (Comp) (1998) La Educación en la Era de la Información. Banco Interamericano de Desarrollo, Cartagena, Colombia.

Ducoing Watty, Patricia y Fortoul Ollivier, Coordinación General (2013) "Procesos de formación, Volumen 1, 2002-2011", de la Colección de los Estados del Conocimiento del COMI., ANUIES-COMIE, México.

Hargreaves, Andy. (2003) Enseñar en la Sociedad del Conocimiento. Ediciones Octaedro. Barcelona.

Imbernón, Francisco (2008) 10 ideas clave. La formación permanente del profesorado. Edit. Graó. Barcelona.

Lizarazo Arias, Diego y Andión Gamboa, Mauricio (directores)(2013) Símbolos Digitales. Representaciones de las TIC en la comunidad escolar. Siglo XXI Editores, México

Mendoza Sánchez, María del Socorro (2014) "Trayectorias escolares de las/los docentes egresados /as de diplomados a distancia en TIC y su incidencia en las prácticas en 
educación primaria." Tesis, Doctorado en Educación UPN-141. Fechada el 25 de junio de 2014.

Mominó, Josep Ma., Sigalés, Carles y Meneses, Julio. (2008) La Escuela en la Sociedad Red. Internet en la educación Primaria y Secundaria. Editorial Ariel, Barcelona.

OCDE (2005), Teachers matter. Attracting, developing and retaining effective teachers. París.

Palacios, Jana, Flores-Roux, Ernesto y García Zaballos, Antonio (2013) "Diagnóstico del sector TIC en México. Conectividad e inclusión social para la mejora de la productividad y el crecimiento económico." DOCUMENTO DE DEBATE \# IDB-DP235. Banco Interamericano de Desarrollo.

Palamidessi, Mariano (Comp.) Galarza, Daniel, Landau, Mariana, Schneider, Débora (2006) La Escuela en la sociedad de redes. Ed. Fondo de Cultura Económica, Buenos Aires, Argentina

Prenski, Mark (2010) Nativos e Inmigrantes Digitales. Cuadernos SEK 2.0 Consultado en www.marcprensky.com/ 30 de diciembre 2014

Revista Mexicana de Investigación Educativa (2010.1) Volumen XV, Número 44. México.

Santiago Benítez, Gisela, Caballero Álvarez, Rebeca, Gómez Mayén, Diana y Domínguez Cuevas, Atenea (2013) El uso didáctico de las TIC en escuelas de educación básica en México. En Revista Latinoamericana de Estudios Educativos, Volumen XLII, Número 3, Paginas 99-111. CEE, México

Sacristán, Ana (Comp.) (2013) Sociedad del Conocimiento, Tecnología y Educación. Ediciones Morata, Madrid.

Shulman, L. (2008), Excellence: an immodest proposal. (ver:http://www.carnegiefoundation.org).

SEP. (2011) Planes y Programas para la Formación de Maestros. México.

Santiago Benites, Gisela, Caballero Alvarez, Rebeca, Gómez Mayén, Diana y Domínguez Cuevas, Atenea. (2013) El uso didáctico de las TIC en las escuelas de educación básica en México. Revista Latinoamericana de Estudios Educativos, Vol. XLIII, 3er trimestre, México.

Tejedor, F.J. y Varcárcel Editores. (1996) Perspectivas de las Nuevas Tecnologías en la Educación. Narcea Ediciones. Madrid.

Villegas, Gustavo Adolfo y Restrepo, Marta Lucia (2012) Diez Mitos sobre la Educación Virtual. Edit. Universidad EAFIT, Medellín, Colombia.

Tesis en Base de Datos;

Campaña Jiménez, Rafael Luis (2012) Innovación a través de las tecnologías de la información y la comunicación en formación profesional. Estudio de caso. Universidad de Granada. Departamento de Didáctica y Organización Escolar. Para ser consultada en http://hdl.handle.net/10481/19678

Alfaro Rodríguez, Ana Paulina (2013) Estudio del uso de las tecnologías de la información y la comunicación en la formación permanente del profesorado para la mejora de la práctica docente. Tesis doctoral inédita leída en la Universidad Autónoma de Madrid, Facultad de Formación de Profesorado y Educación, Departamento de Didáctica y Teoría de la Educación. Para ser consultada en http://hdl.handle.net/10803/113680

Ramírez Culebro, Claudia María (2012) Análisis de las competencias básicas en Tecnologías de la Información y Comunicación (TIC) del profesorado de Educación Primaria: un plan de formación. Municipio de Comitán, Chiapas, México. Universitat Autònoma de Barcelona. Departament de Pedagogia Sistemàtica i Social 